\title{
PENGARUH KEPERCAYAAN DIRI DAN PENGUASAAN KOSAKATA TERHADAP KETERAMPILAN BERBICARA BAHASA INGGRIS SISWA
}

\author{
Maria Adelina \\ Program Studi Teknik Informatika, Universitas Indraprasta PGRI Jakarta \\ Email: adelinasaragih@gmail.com
}

\begin{abstract}
Abstrak
Tujuan dari penelitian ini adalah untuk mengetahui pengaruh kepercayaan diri dan penguasaan kosakata terhadap keterampilan berbicara bahasa Inggris. Metode penelitian yang digunakan adalah survei dengan teknik korelasional. Metode penelitian ini digunakan untuk mencari hubungan antar variabel penelitian. Sampel dalam penelitian ini sebanyak 138 siswa dari SMA Negeri di Jakarta Timur yaitu SMAN 39 dan SMAN 88 pada tahun penelitian 2014. Hasil analisis menunjukkan bahwa: 1) Terdapat pengaruh yang signifikan kepercayaan diri dan penguasaan kosakata secara bersama-sama terhadap keterampilan berbicara bahasa Inggris. Hal ini dibuktikan dengan perolehan nilai $\mathrm{F}_{\mathrm{o}}=11,130$ dan Sig. $0,000<0,05$. Secara bersama-sama variabel kepercayaan diri dan penguasaan kosakata memberikan kontribusi sebesar $14,2 \%$ terhadap variabel keterampilan berbicara bahasa Inggris siswa. 2) Terdapat pengaruh yang signifikan kepercayaan diri terhadap keterampilan berbicara bahasa Inggris. Hal ini dibuktikan dengan perolehan nilai $t_{\text {hitung }}=3,987$ dan Sig. $0,000<0,05$. Variabel kepercayaan diri memberikan kontribusi sebesar 9,83\% dalam meningkatkan keterampilan berbicara bahasa Inggris. 3) Terdapat pengaruh yang signifikan penguasaan kosakata terhadap keterampilan berbicara bahasa Inggris siswa. Hal ini dibuktikan dengan perolehan nilai $t_{\text {hitung }}=2,699$ dan Sig. 0,008 $<0,05$. Variabel penguasaan kosakata memberikan kontribusi sebesar 4,32 \% dalam meningkatkan keterampilan berbicara bahasa Inggris siswa.
\end{abstract}

Kata Kunci: kepercayaan diri, penguasaan kosakata, keterampilan berbicara bahasa Inggris

\begin{abstract}
This research aims to show the effects of self-confidence and vocabulary mastery on English speaking skill. The method used in this research is a survey method with correlation technique. It is used to show a correlation between research variables. The sample of this research consists of 138 students from SMAN in East Jakarta, namely SMAN 39 and SMAN 88 in 2014. The result of the research shows that: 1) There are jointly significant effects of self-confidence and vocabulary mastery on English speaking skill, as proven by the value of $F_{O}=11,130$ and Sig. 0,000<0,05, meaning that self-confidence and vocabulary mastery variables jointly make a contribution of $14.2 \%$ to student's English speaking skill. 2) There is a significant effect of self-confidence on English speaking skill, as seen by the value of $t_{O}$ $=3,987$ and Sig. 0,000 <0,05, indicating that self-confidence variable makes a contribution of $9.83 \%$ towards improving student's English speaking skill. 3) There is a significant effect of vocabulary mastery on student's English speaking skill, as shown by the value of $t_{O}=$ 2,699 and Sig. 0,008 < 0,05, meaning that vocabulary mastery variable makes a contribution of 4,32\% towards improving student's English speaking skill.
\end{abstract}

Key Words: self-confidence, vocabulary mastery, English speaking skill

\section{Pendahuluan}

Salah satu keterampilan berbahasa adalah keterampilan berbicara. Agar seseorang mampu dan terampil dalam berbicara dan berbahasa diperlukan rasa percaya diri dalam berbicara dan pembendaharaan kata menjadi salah satu kunci suksesnya berbahasa. Penguasaan kosakata yang memadai akan membuat seseorang mampu melakukan komunikasi dengan bahasa. Makin banyak kosakata yang dikuasai maka lebih memudahkan seseorang menerima atau menyampaikan informasi yang lebih luas dan kompleks. 
Keterampilan berbicara merupakan suatu kemampuan berbicara lancar dan mahir dalam mengungkapkan isi pikiran atau gagasan. Untuk mengembangkan kemampuan ini, pembicara selain menguasai kosakata dan frasa, pengucapan yang tepat, harus memiliki rasa percaya diri dalam berbicara (Confidence Speaking). Berbicara dengan percaya diri (Confidence Speaking) adalah kemampuan tahap awal berbicara dalam bentuk paparan atau gagasan secara detail, lebih terurai dan tanpa rasa takut dalam mengungkapkannya. Kendala mencapai tahap ini adalah lingkungan yang tidak berbahasa Inggris dan tidak adanya orang asing di lingkungan siswa yang gemar menekuni bahasa Inggris.

Melalui peningkatan kepercayaan diri, siswa diharapkan memiliki keberanian untuk terampil dalam bahasa Inggris khususnya berbicara (speaking), menjadi meningkat pula. Dengan meningkatnya kepercayaan diri pada diri siswa tersebut, diharapkan siswa dengan sendirinya dapat menggunakan kosakata yang diperoleh untuk berkomunikasi dengan terampil. Dalam kegiatan belajar mengajar, hendaknya guru lebih memberikan peluang siswa untuk aktif, meningkatkan rasa keingintahuan siswa dan memunculkan kepercayaan diri siswa dalam belajar.

Masalah ketidakmampuan mencapai tahap percaya diri dalam berbicara (Confidence Speaking) adalah tidak bisa mengingat kosakata dalam berbicara, tidak mampu menyusun kata-kata menjadi kalimat yang benar dan bermakna, sehingga proses berkomunikasi berubah menjadi kaku dan tidak percaya diri. Tidak dapat mengingat kosakata dan ketidakmampuan menyusun kosakata dalam kalimat disebabkan tidak terlatih berbicara panjang dalam bentuk menguraikan, memaparkan gagasan dan menyampaikan informasi.

Menguasai kosakata tidak mudah. Ia perlu diucapkan berulang-ulang dan berlatih menyusunnya secara oral dan tulisan. Latihan menyusun kata-kata dalam percakapan dapat membentuk berbicara secara alami. Situasi ini perlu diciptakan dalam proses belajar.

Strategi mengembangkan kosakata dapat dilakukan melalui banyak membaca, mendengar, mengucapkan dan menuliskannya berulangkali. Sebuah teks bacaan memberi kontribusi yang besar terhadap keempat keterampilan berbahasa Inggris. Selain memperoleh banyak kosakata baru, pembaca belajar cara mengucap (pronounciation) yang benar dan memantapkan kosakata yang sudah diperoleh. Penggunaannya dapat diaplikasikan dalam percakapan seperti dalam diskusi, tanya jawab, mencari informasi, memberi laporan, permainan atau menceritakan kembali.

Berdasarkan latar belakang dan permasalahan rendahnya kepercayaan diri siswa dan kurangnya penguasaan kosakata siswa dalam berbicara bahasa Inggris sehari-hari maka dilakukan penelitian dalam hal ini agar ditemukan fakta demi perbaikan proses pembelajaran sehingga proses belajar-mengajar berhasil dengan baik.

Penelitian ini bertujuan untuk mengetahui apakah kepercayaan diri dan penguasaan kosakata berpengaruh signifikan terhadap keterampilan berbicara bahasa Inggris. Penelitian ini diharapkan dapat memperkaya pengetahuan dan wawasan mengenai ilmu pendidikan khususnya tentang pendidikan bahasa Inggris serta menjadi pedoman bagi penelitian sejenis di masa yang akan datang.

\section{Tinjauan Pustaka}

Menurut Crystal (2003: 1) bahwa: "English is the global language they would say, you hear it on television spoken by politican from all over the world, wherever you travel you are see English signed and advisement, wherever you enter a hotel or restaurant in a foreign city they will be understand English, and there will be an English menu". Crystal menyatakan bahwa bahasa Inggris merupakan bahasa global yang digunakan di seluruh dunia, bahasa Inggris sebagai alat komunikasi ketika kita bepergian ke negara lain, ketika kita masuk ke 
hotel dan restoran di negara lain mereka mengerti bahasa Inggris dan menyajikan menu makanan dalam bahasa Inggris. Bahasa Inggris juga digunakan dalam media massa untuk menyampaikan informasi seperti televisi, koran, majalah, dan lain sebagainya, sehingga bahasa Inggris menjadi begitu dikenal di kalangan dunia internasional.

Dalam pengajaran dan pembelajaran bahasa asing, kemampuan untuk berbicara adalah keterampilan yang paling penting karena merupakan dasar untuk komunikasi dan keterampilan yang paling sulit. Berbahasa Inggris adalah yang paling sulit bagi peserta didik. Berbicara adalah keterampilan yang paling penting dan esensial. Penguasaan keterampilan ini menggambarkan bahwa pembicara memiliki pengetahuan yang tepat dari bahasa. "In foreign language teaching and learning, ability to speak is the most essential skill since it is the basic for communication and it is the most difficult skill. Speaking English is the most difficult for learners. Speaking is the most important and essential skill. Mastery of this skill illustrates that the speaker possesses precise knowledge of language”. (Oradee, 2012: 533)

Harmer (2007: 123) berpendapat bahwa: "Firstly, speaking activities provide rehearsal opportunities-chances to practise real-life speaking in the safety of the classroom. Secondly, speaking tasks in which students try to use any or all of the language they know provide feedback for both teacher and students. Everyone can see how well they are doing: both how successful they are, and also what language problems they are experiencing”. Kegiatan berbicara memberikan kesempatan-kesempatan latihan untuk mempraktekkan berbicara dalam kehidupan nyata di dalam kenyamanan kelas. Tugas berbicara di mana siswa-siswa mencoba menggunakan salah satu atau semua bahasa yang mereka tahu dengan memberikan umpan balik untuk guru dan siswa. Setiap orang dapat melihat seberapa baik mereka lakukan, seberapa sukses mereka, dan masalah bahasa apa yang mereka alami.

Lauster (1978: 13) menyatakan bahwa: "Self confidence has much to do with personality, development, and psychological stability. Self confidence also associated with well being, happiness. Whereas low level of self-confidence increase the probability that one will be at risk of anxiety, tension, and depression”. Kepercayaan diri berkaitan dengan kepribadian, perkembangan, dan stabilitas psikologis. Kepercayaan diri juga berhubungan dengan kesejahteraan dan kebahagiaan. Sedangkan rendahnya tingkat kepercayaan diri dapat meningkatkan kemungkinan resiko kecemasan, ketegangan, dan depresi. Hal ini dapat mempengaruhi seseorang dalam berbicara sehingga pembicaraan menjadi kurang efektif.

Menurut Tunçel (2015: 2576): "Encouraging students to act and speak correctly, giving them feedbacks -especially positive feedbacks instantly, and offering them in-class activities they will enjoy can improve their self-confidence". Salah satu cara mendorong siswa untuk bertindak dan berbicara dengan benar yaitu dengan memberi masukan positif secara langsung dan menawarkan kegiatan di kelas sehingga mereka akan senang dan dapat meningkatkan kepercayaan dirinya.

"Self confidence is an attitude which allows individuals to have positive yet realistic views of themselves and their situations. Self confident people trust their own abilities, have a general sense of control in their lives, and believe that, within reason, they will be able to do what they wish, plan, and expect" (Reddy, 2014: 56). Percaya diri adalah sikap yang memungkinkan individu untuk memiliki pandangan yang positif namun realistis dari diri mereka sendiri dan di setiap situasi. Orang yang percaya diri, percaya pada kemampuan mereka sendiri, dapat mengontrol hidup mereka, dan percaya bahwa mereka dapat melakukan apa yang mereka inginkan, rencanakan dan mereka harapkan. 
Richards dan Renandya (2002: 225) mengemukakan bahwa: "Vocabulary is a core component of language proficiency and provides much of the basis for how well learners speak, listen, read and write". Kosakata adalah komponen inti dari kecakapan berbahasa dan memberikan banyak dasar untuk siswa tentang bagaimana peserta didik berbicara dengan baik, mendengarkan, membaca dan menulis.

Kosakata yang baik lebih penting dibandingkan tata bahasa atau struktur kalimat dalam pemahaman bahasa dan komunikasi. Hal ini diungkapkan oleh Thornbury (2002: 13) yang mengatakan bahwa: "If you spend most of your time studying grammar, your English will not improve very much. You will see most improvement if you learn more words and expressions. You can say very little with grammar, but you can say almost anything with words".

Schmitt dan Mc. Carthey (1997: 1353) mengatakan bahwa: "Vocabulary is one of the most important skills in a language. We can't speak well if we do not master it. No matter how well the students learn grammar, no matter how successfully the sound of foreign language is mastered, without words to express a wider a range of meanings, communication in a foreign language just cannot happen in any meaningful way”. Kosakata adalah salah satu keterampilan yang paling penting dalam suatu bahasa. Kita tidak bisa berbicara dengan baik jika kita tidak menguasainya. Tidak peduli seberapa baik siswa belajar tata bahasa, tidak peduli seberapa sukses bahasa asing dikuasai, tanpa kata-kata untuk mengungkapkan makna yang lebih luas, komunikasi dalam bahasa asing tidak berarti. "Without vocabulary knowledge, words are just words without much meaning” (Neuman and Wright, 2014: 6). Tanpa pengetahuan kosakata, kata hanyalah kata tanpa mengandung banyak makna.

\section{Metodologi Penelitian}

Penelitian ini dilaksanakan pada tahun 2014 di SMA Negeri 39 yang berlokasi di Komplek Kopassus, Jalan RA. Fadillah Cijantung yang berada di wilayah Jakarta Timur. Waktu penelitian mulai dari proses perijinan, penyampaian proposal, pencarian data, pengolahan data sampai dengan proses analisis dan penyajian hasil penelitian membutuhkan waktu sekitar 6 bulan. Metode yang digunakan dalam penelitian kuantitatif ini adalah metode survei dengan analisis korelasional. Variabel penelitian ini terdiri dari satu variabel terikat yaitu Keterampilan Berbicara Bahasa Inggris $(\mathrm{Y})$ dan dua variabel bebas yaitu Kepercayaan Diri $\left(\mathrm{X}_{1}\right)$ dan Penguasaan Kosakata $\left(\mathrm{X}_{2}\right)$.

Populasi dalam penelitian ini adalah siswa SMA Negeri 39 dan SMA Negeri 88 di Jakarta Timur. Populasi terjangkau adalah siswa kelas $\mathrm{X}$ dari kelas yang terpilih secara acak yang berjumlah 764 siswa. Dari jumlah populasi yang telah ditetapkan diambil sampel dengan menggunakan teknik Simple Random Sampling (Sampling Acak Sederhana), di mana tiaptiap individu dalam populasi mempunyai hak yang sama menjadi anggota sampel. Teknik sampling random dilakukan secara acak. Pertama-tama ditentukan 3 kelas yang menjadi sampel. Kemudian, dipilihlah 3 kelas secara acak dari sekolah SMA Negeri di Jakarta Timur. Dari 3 kelas yang telah terpilih secara acak tersebut terdapat 764 siswa kelas X. Dari 764 siswa kelas X terpilihlah 138 siswa sebagai responden dalam penelitian ini.

Untuk mendapatkan data yang diperlukan dalam penelitian ini digunakan teknik pengumpulan data berupa tes lisan berbentuk unjuk kerja berpidato untuk mendapatkan data tentang keterampilan berbicara bahasa Inggris siswa, tes objektif berbentuk pilihan ganda untuk mendapatkan data tentang penguasaan kosakata siswa dan angket atau kuesioner untuk mengetahui tingkat kepercayaan diri siswa.

Analisis deskriptif dilakukan untuk mencari harga rata-rata, ragam, simpangan baku, distribusi frekuensi, mean, median, modus, pembautan histogram dari skor Y (Keterampilan 
Berbicara), skor $\mathrm{X}_{1}$ (Kepercayaan Diri) dan skor $\mathrm{X}_{2}$ (Penguasaan Kosakata). Uji normalitas dilakukan untuk mengetahui apakah data dari masing-masing sampel peubah bersifat normal. Normalitas data hanya dikenakan terhadap variabel terikat (Y). Untuk menganalisis ketergantungan satu peubah terikat (Y) terhadap sejumlah peubah bebas (X) atau untuk mengetahui pengaruh beberapa peubah $\mathrm{X}$ terhadap peubah $\mathrm{Y}$ digunakan metode Analisis Regresi Linier. Kuat tidaknya hubungan antara peubah X dengan peubah Y dihitung dengan analisis statistik koefisien korelasi berganda $(\mathrm{R})$. Tingkat signifikansi koefisien regresi linier berganda, diketahui dengan uji F, yaitu membandingkan nilai $\mathrm{F}$ hitung dengan $\mathrm{F}$ tabel.

\section{Hasil dan Pembahasan}

Tabel 1. Hasil Perhitungan Pengujian Koefisien Korelasi Ganda Variabel $\mathrm{X}_{1}$ dan $\mathrm{X}_{2}$ terhadap $\mathrm{Y}$

\begin{tabular}{lcccc}
\hline \multicolumn{4}{c}{ Model Summary } \\
\hline Model & $\mathrm{R}$ & $R$ Square & $\begin{array}{l}\text { Adjusted } R \\
\text { Square }\end{array}$ & $\begin{array}{l}\text { Std. Error of the } \\
\text { Estimate }\end{array}$ \\
\hline 1 & $0,376^{\text {a }}$ & 0,142 & 0,129 & 10,248 \\
\hline a. Predictors: (Constant), Penguasaan & Kosakata, Kepercayaan Diri \\
\hline
\end{tabular}

Tabel 2. Hasil Perhitungan Pengujian Signifikansi Koefisien Regresi Variabel $X_{1}$ dan $X_{2}$ terhadap $Y$

\begin{tabular}{|c|c|c|c|c|c|c|}
\hline \multicolumn{7}{|c|}{ ANOVA $^{\mathrm{a}}$} \\
\hline Model & & $\begin{array}{l}\text { Sum of } \\
\text { Squares }\end{array}$ & $d f$ & Mean Square & $F$ & Sig. \\
\hline \multirow[t]{3}{*}{1} & Regression & 2337,856 & 2 & 1168,928 & 11,130 & $0,000^{\mathrm{b}}$ \\
\hline & Residual & 14178,267 & 135 & 105,024 & & \\
\hline & Total & 16516,123 & 137 & & & \\
\hline $\begin{array}{l}\text { a. } \mathrm{De} \\
\text { b. } \operatorname{Pr}\end{array}$ & $\begin{array}{l}\text { dent Varial } \\
\text { ors: (Cons }\end{array}$ & $\begin{array}{l}\text { eterampilan } \mathrm{H} \\
\text { Penguasaan } \mathrm{I}\end{array}$ & $\begin{array}{l}\text { icar } \\
\text { akat }\end{array}$ & $\begin{array}{l}\text { ahasa Inggris } \\
\text { Kepercayaan } D\end{array}$ & & \\
\hline
\end{tabular}

Tabel 3. Hasil Perhitungan Persamaan Regresi Ganda Variabel $X_{1}$ dan $X_{2}$ terhadap $Y$

\begin{tabular}{|c|c|c|c|c|c|c|}
\hline \multicolumn{7}{|c|}{ Coefficients $^{a}$} \\
\hline & & \multicolumn{2}{|c|}{$\begin{array}{l}\text { Unstandardized } \\
\text { Coefficients }\end{array}$} & \multirow{2}{*}{$\begin{array}{l}\text { Standardized } \\
\text { Coefficients } \\
\text { Beta }\end{array}$} & \multirow[t]{2}{*}{$t$} & \multirow[t]{2}{*}{ Sig. } \\
\hline & & $B$ & Std, Error & & & \\
\hline \multirow[t]{3}{*}{1} & (Constant) & 41,020 & 9,366 & & 4,380 & 0,000 \\
\hline & Kepercayaan Diri & 0,285 & 0,072 & 0,318 & 3,987 & 0,000 \\
\hline & $\begin{array}{l}\text { Penguasaan } \\
\text { Kosakata }\end{array}$ & 0,234 & 0,087 & 0,215 & 2,699 & 0,008 \\
\hline
\end{tabular}

1. Pengaruh Kepercayaan diri $\left(\mathrm{X}_{1}\right)$ dan Penguasaan kosakata $\left(\mathrm{X}_{2}\right)$ secara bersama-sama terhadap Keterampilan berbicara bahasa Inggris (Y).

Hipotesis yang diuji:

$H_{0}: \beta_{y 1}=\beta_{y 2}=0$

$H_{1}: \beta_{y 1} \neq 0, \beta_{y 2} \neq 0$

Artinya:

$\mathrm{H}_{0}$ : Tidak terdapat pengaruh kepercayaan diri dan penguasaan kosakata secara bersamasama terhadap keterampilan berbicara bahasa Inggris.

$\mathrm{H}_{1}$ : Terdapat pengaruh kepercayaan diri dan penguasaan kosakata secara bersama-sama terhadap keterampilan berbicara bahasa Inggris. 
Dari Tabel 2 dapat dinyatakan bahwa terdapat pengaruh yang signifikan kepercayaan diri dan penguasaan kosakata secara bersama-sama terhadap keterampilan berbicara bahasa Inggris. Hal ini dibuktikan dengan perolehan nilai Fo $=11,130$ dan Sig. 0,000 0,05. Sementara itu, persamaan garis regresi ganda dapat dinyatakan dengan $\hat{Y}=41,020+$ $0,285 \mathrm{X} 1+0,234 \mathrm{X} 2$. Hal ini memiliki pengertian bahwa variabel kepercayaan diri dan penguasaan kosakata memberikan kontribusi positif terhadap variabel keterampilan berbicara bahasa Inggris siswa.

Dari Tabel 1 juga dapat menjelaskan bahwa secara bersama-sama variabel kepercayaan diri dan penguasaan kosakata memberikan kontribusi sebesar 14,2 \% terhadap variabel keterampilan berbicara bahasa Inggris siswa. Hal ini mengandung arti bahwa kepercayaan diri dan penguasaan kosakata telah memberikan pengaruh yang signifikan terhadap keterampilan berbicara bahasa Inggris siswa SMA Negeri di Jakarta Timur.

Kepercayaan diri adalah salah satu faktor yang berpengaruh terhadap kefasihan seseorang dalam berkomunikasi dengan terampil menggunakan bahasa Inggris. Banyak orang yang ingin terampil berbahasa Inggris tetapi setelah mengalami sedikit kesulitan, mereka lalu menyerah dan tidak mau mencoba lagi. Di sinilah pentingnya peran kepercayaan diri yang dapat mendukung setiap siswa dalam meningkatkan keterampilan berbicara bahasa Inggris. Situasi ini perlu diciptakan dalam proses belajar. Strategi mengembangkan kosakata dapat dilakukan melalui banyak latihan membaca, mendengar, mengucapkan dan menuliskannya berulangkali.

Skinner (2013: 3) mengungkapkan bahwa: "Confidence is a quality found in many aspects of society. Therefore, confidence isn't a stranger to sport, when it can be associated with qualities like mental toughness, poise, grit, belief, courage, and heart. These qualities are descriptive verbs that are constantly used when describing someone who is successful". Kepercayaan diri adalah kualitas yang ditemukan dalam banyak aspek di masyarakat. Oleh karena itu, kepercayaan diri ketika dikaitkan dengan kualitas seperti ketangguhan mental, ketenangan, keyakinan, keberanian. Kualitas ini adalah kata kerja deskriptif yang terus digunakan ketika menggambarkan orang yang sukses.

Napa (1999: 1) berpendapat bahwa: "Vocabulary is one of the components of language exists without word. Word are symbols for ideas. They are the means by which people exchange their thought. The more words we learn, the more ideas we should have to that we can communicate the ideas more effectively". Kosakata adalah salah satu komponen bahasa. Kata adalah simbol-simbol dari ide-ide. Kata-kata adalah sarana orang untuk saling bertukar pikiran. Semakin banyak kata yang kita pelajari, maka semakin banyak ide yang kita dapat dan mengkomunikasikan ide-ide tersebut dengan lebih efektif.

2. Pengaruh Kepercayaan diri $\left(\mathrm{X}_{1}\right)$ terhadap Keterampilan berbicara bahasa Inggris ( $\left.\mathrm{Y}\right)$

Hipotesis yang diuji:

$H_{0}: \beta_{y 1}=0$

$H_{1}: \beta_{y 1} \neq 0$

Artinya:

$\mathrm{H}_{0}$ : Tidak terdapat pengaruh kepercayaan diri terhadap keterampilan berbicara bahasa Inggris.

$\mathrm{H}_{1}$ : Terdapat pengaruh kepercayaan diri terhadap keterampilan berbicara bahasa Inggris.

Dari Tabel 3 dapat dinyatakan bahwa terdapat pengaruh yang signifikan kepercayaan diri terhadap keterampilan berbicara bahasa Inggris. Hal ini dibuktikan dengan perolehan nilai 
$\mathrm{t}_{\text {hitung }}=3,987$ dan Sig. 0,000 $<0,05$. Adapun kontribusi variabel kepercayaan diri terhadap keterampilan berbicara bahasa Inggris dapat dinyatakan dengan rumus:

$$
\begin{aligned}
& \mathrm{KD}=\text { Nilai } \beta_{x 1 y} \times \text { Nilai Korelasi Parsialnya }\left(r_{x 1 y}\right) \times 100 \% \\
& \mathrm{KD}=0,318 \times 0,309 \times 100 \%=9,83 \%
\end{aligned}
$$

Dari hasil perhitungan di atas dapat dinyatakan bahwa kontribusi kepercayaan diri dalam meningkatkan keterampilan berbicara bahasa Inggris siswa sebesar 9,83\%. Salah satu faktor yang sangat penting yang mempengaruhi keterampilan berbicara adalah faktor dari dalam (internal) dari segi psikologi yaitu percaya diri. Faktor ini akan mempengaruhi seseorang dalam berbicara sehingga suatu pembicaraan dapat berlangsung secara efektif.

"As we all know that how much self confidence is important in one's life. Self confidence is extremely important in almost every aspect of our lives, yet so many people struggle to find it" (Sharma and Sahu, 2013: 1212). Seperti yang kita semua tahu bahwa kepercayaan diri begitu penting dalam kehidupan seseorang. Kepercayaan diri sangat penting hampir di setiap aspek kehidupan kita, namun begitu banyak orang berjuang untuk menemukan rasa percaya diri itu.

"Self-confidence has a key characteristics to start any action especially for speaking. Among all other language skills, speaking is of an exclusive place to have effective communication, and self-confidence is one of the facilitators to start conversation" (Gurler, 2015: 1). Kepercayaan diri memiliki sebuah kunci karakteristik untuk memulai tindakan apapun terutama untuk berbicara. Di antara semua keterampilan bahasa lain, berbicara adalah tempat eksklusif untuk memiliki komunikasi yang efektif, dan kepercayaan diri adalah salah satu fasilitator untuk memulai percakapan.

Myers (1988: 358) mengatakan bahwa: Tingkat percaya diri yang tinggi mengindikasikan orang mampu berbicara dengan tenang, mampu berkomunikasi dengan jelas dengan bahasa yang sederhana. Dengan demikian dapat disimpulkan bahwa tingkat percaya diri yang tinggi berpengaruh terhadap keterampilan berbicara.

3. Pengaruh Penguasaan kosakata $\left(\mathrm{X}_{2}\right)$ terhadap Keterampilan berbicara bahasa Inggris $(\mathrm{Y})$ Hipotesis yang diuji:

$H_{0}: \beta_{y 2}=0$

$H_{1}: \beta_{y 2} \neq 0$

Artinya:

$\mathrm{H}_{0}$ : Tidak terdapat pengaruh penguasaan kosakata terhadap keterampilan berbicara bahasa Inggris.

$\mathrm{H}_{1}$ : Terdapat pengaruh penguasaan kosakata terhadap keterampilan berbicara bahasa Inggris.

Dari Tabel 3 dapat dinyatakan bahwa terdapat pengaruh yang signifikan penguasaan kosakata terhadap keterampilan berbicara bahasa Inggris siswa. Hal ini dibuktikan dengan perolehan nilai $t_{\text {hitung }}=2,699$ dan Sig. 0,008 $<0,05$. Adapun kontribusi variabel penguasaan kosakata terhadap keterampilan berbicara bahasa Inggris dapat dinyatakan dengan rumus:

$$
\begin{aligned}
& \mathrm{KD}=\text { Nilai } \beta_{x 2 y} \times \text { Nilai Korelasi Pasialnya }\left(r_{x 2 y}\right) \times 100 \% \\
& \mathrm{KD}=0,215 \times 0,201 \times 100 \%=4,32 \%
\end{aligned}
$$

Dari hasil perhitungan di atas dapat dinyatakan bahwa kontribusi penguasaan kosakata dalam meningkatkan keterampilan berbicara bahasa Inggris siswa sebesar 4,32 \%. Unsur 
bahasa dari segi Linguistik terdiri dari kosakata (vocabulary), kalimat (sentence), suara (pronounciation) dan fungsi bahasa (language function). Artinya, permasalahan komunikasi berkisar tentang penguasaan kosakata, pengucapan, ekspresi menurut fungsi.

Nemati (2009: 014) mengatakan bahwa: "Although some teachers may think that vocabulary learning is easy, learning new vocabulary items has always been challenging for the learners". Meskipun beberapa guru mungkin berpikir bahwa mempelajari kosakata mudah, mempelajari kosakata baru selalu menantang untuk peserta didik.

Tarigan (1986: 2) menyatakan bahwa kualitas dan kuantitas berbahasa seseorang bergantung pada kualitas kosakata yang dimiliki. Makin kaya kosakata yang dimiliki maka makin besar pula kemungkinan ia terampil berbahasa.

Kata adalah alat penting untuk komunikasi. Ketika kita membaca sebuah teks, kita sebenarnya membaca kata-kata yang merupakan simbol dari makna. Selama proses membaca, kita menafsirkan simbol-simbol dengan memberikan makna yang berbeda. Dengan demikian, kita membaca kata-kata bukan teks. Tujuan pengajaran kosakata adalah untuk menciptakan penyimpanan makna/arti kata dan informasi yang berkaitan dengan kata-kata dalam memori jangka panjang siswa, yang mana mengarah pemahaman siswa. Belajar dari konteks bukanlah proses jangka pendek. "Word is the essential instrument for communication. When we read a text, we actually read the words and they are symbols of meanings. During reading process, we interpret those symbols by assigning them different meanings. Thus, we read the words not the texts. The goal of teaching vocabulary is to create storage of words meanings and the information related to those words in the learners long-term memory, which leads student comprehension. Learning from context is not a short-term process". (Tiryaki and Tutunis, 2013: 210)

Syarat utama mempelajari kosakata baru adalah dengan mencari daftar kosakata yang akan dipelajari dan belum diketahui dengan membaca bahan-bahan literatur Inggris, termasuk film, lirik lagu, kamus dan artikel-artikel bacaan berbahasa Inggris di buku, jurnal, atau majalah. Syarat ini haruslah diutamakan oleh seorang tenaga pengajar ketika ingin mengajarkan kosakata baru kepada para peserta didiknya. Dengan mencari bahan dan sering membaca serta mengaplikasikannya dalam berbicara dan menulis merupakan salah satu faktor penentu dalam upaya memperkaya pengetahuan kita dan dengan demikian dapat memperkaya perbendaharaan kosakata bahasa Inggris yang kita perlukan untuk dapat menggunakan bahasa Inggris baik secara aktif maupun pasif. Ketika seorang siswa tidak memiliki minat untuk memperkaya kosakata bahasa Inggris mereka, maka yang terjadi adalah ketidakmampuan untuk menggunakan bahasa Inggris sebagai alat komunikasi.

Disadari sepenuhnya bahwa dalam penelitian ini terdapat beberapa kekurangan baik dalam proses penyelesaian maupun hasil penelitian yang diperoleh yang dianggap sebagai keterbatasan penelitian dikarenakan penelitian ini menggunakan soal dan kuesioner sebagai instrumen untuk mendapatkan data, di mana pilihan jawaban dalam instrumen mengarahkan siswa hanya untuk menjawab satu dari lima pilihan jawaban, padahal mungkin pilihan jawaban tersebut tidak sesuai dengan keinginannya.

\section{Simpulan dan Saran \\ Simpulan}

Pada bagian simpulan ini, penulis uraikan secara singkat hasil penelitian yang diperoleh di lapangan sebagai berikut:

1. Terdapat pengaruh yang signifikan kepercayaan diri dan penguasaan kosakata secara bersama-sama terhadap keterampilan berbicara bahasa Inggris. Hal ini dibuktikan dengan 
perolehan nilai Fo $=11,130$ dan Sig. $0,000<0,05$. Secara bersama-sama variabel kepercayaan diri dan penguasaan kosakata memberikan kontribusi sebesar 14,2 \% terhadap variabel keterampilan berbicara bahasa Inggris siswa.

2. Terdapat pengaruh yang signifikan kepercayaan diri terhadap keterampilan berbicara bahasa Inggris. Hal ini dibuktikan dengan perolehan nilai $t_{\text {hitung }}=3,987$ dan Sig. $0,000<$ 0,05 . Variabel kepercayaan diri memberikan kontribusi sebesar $9,83 \%$ dalam meningkatkan keterampilan berbicara bahasa Inggris.

3. Terdapat pengaruh yang signifikan penguasaan kosakata terhadap keterampilan berbicara bahasa Inggris siswa. Hal ini dibuktikan dengan perolehan nilai $\mathrm{t}_{\text {hitung }}=2,699$ dan Sig. $0,008<0,05$. Variabel penguasaan kosakata memberikan kontribusi sebesar 4,32\% dalam meningkatkan keterampilan berbicara bahasa Inggris siswa.

\section{Saran}

Karena penelitian ini hanya terbatas pada dua variabel bebas yaitu kepercayaan diri dan penguasaan kosakata, maka disarankan agar peneliti lain dapat mengadakan penelitian lebih lanjut dengan menambah atau mengganti variabel-variabel bebasnya dan menggunakan materi yang lebih banyak serta populasi yang lebih luas.

\section{Daftar Pustaka}

Crystal, D. (2003). English As a Global Language. Cambridge: Cambridge University Press.

Gurler, İ. (2015). Correlation between Self-confidence and Speaking Skill of English Language Teaching and English Language and Literature Preparatory Students. Curr Res Soc Sci, Vol. 1 No. 2 Tahun 2015. 14-19.

Harmer, J. (2007). The Practice of English Language Teaching $\left(4^{\text {th }}\right.$ ed). Harlow, U.K.: Longman.

Lauster, P. (1978). The Personality Test. London: Pan Books.

Myers, D. (1988). Social Psychology. New York: McGraw-Hill Companies.

Napa, A. Pitcher. (1999). Vocabulary Development Skills. Yogyakarta: Kanisius.

Nemati, A. (2009). Memory Vocabulary Learning Strategies and Long-term Retention. International Journal of Vocational and Technical Education, Vol. 1 No. 2 Tahun 2009. 014-024.

Neuman, S.B., and Wright, T.S. (2014). The Magic of Words: Teaching Vocabulary in the Early Childhood Classroom. American Educator, Vol. 38 No. 2 Tahun 2014. 4-13.

Oradee, T. (2012). Developing Speaking Skills Using Three Communicative Activities (Discussion, Problem-Solving, and Role-Playing). International Journal of Social Science and Humanity, Vol. 2 No. 6 Tahun 2012. 533-535.

Reddy, M. M. (2014). A Study of Self Confidence in Relation to Achievement Motivation of D.ed Students. Global Journal for Research Analysis, Vol. 3 No. 8 Tahun 2014. 5658.

Richards, J.C., and Renandya, W.A. (2002). Methodology in Language Teaching: An Anthology of Current Practice. Cambrige: Cambridge University Press.

Schmitt, N., \& McCarthy, M. (Eds). (1997). Vocabulary, Description, Acquisition, and Pedagogy: Vocabulary Learning Strategies. Cambridge: Cambridge University Press. 
Sharma, S., and Sahu, D. (2013). Effect of Social Networking Sites on Self Confidence. International Journal of Information and Computation Technology, Vol. 3 No. 11 Tahun 2013. 1211-1216.

Skinner, B. R. (2013). The Relationship Between Confidence and Performance Throughout a Competitive Season. All Graduate Plan B and other Reports, Paper Utah State University. United States.

Tarigan, H.G. (1986). Pengajaran Kosakata. Bandung: Angkasa.

Thornbury, S. (2002). How to Teach Vocabulary. Harlow, U.K.: Longman.

Tiryaki, Z. M., \& Tütüniş, B. (2013). The Role of Extensive Reading on Vocabulary. ELT Research Journal, No. 1, Vol. 4 Tahun 2013. 209-215.

Tunçel, H. (2015). The Relationship between Self Confidence and Learning Turkish as A Foreign Language. Academic Journals, Vol. 10 No. 18 Tahun 2015. 2575-2589. 